\title{
THE IMPLEMENTATION OF AUTOCRATIC AND \\ CHARISMATIC LEADERSHIP MODEL AT ISLAMIC HIGHER EDUCATION IN AN ISLAMIC BOARDING SCHOOL ENVIRONMENT (STUDY AT STAI DDI MANGKOSO)
}

\author{
Muthahhir Arif ${ }^{1}$ \\ Mansyur Ramli \\ Abdul Rahman Mus ${ }^{3}$ \\ Andi Bunyamin ${ }^{4}$ \\ Universitas Muslim Indonesia ${ }^{1,2,3,4}$ \\ azizeh833@gmail.com ${ }^{1}$
}

\begin{abstract}
Leadership in the pesantren environment has an interesting dynamic. This environmental base is generally religious with leadership that is patronized by religious leaders such as kyai, then stereotypes are built in people's understanding that the kyai is the sole leader in a pesantren, or it is common for every pesantren to be cared for and led by a kyai who makes the position of this leader the single colour of leadership. in the pesantren environment. This research is interactive qualitative research with descriptive quantitative analysis. Data retrieval used questionnaires, historical data that already exists. This study used data collection techniques using observation, questionnaire, interview, and documentation techniques. The validity of the research data was checked by using triangulation. The results show that the autocratic leadership model sees the organization as a mechanical tool and all decisions are in the hands of the leader, while the charismatic leadership model can include believing the truth from the leader, accepting what the leader says without asking, carrying out tasks based on the awareness and direction of the leader, encouraging employees in achieving the mission of the institution, encouraging employees to improve performance.
\end{abstract}

Keywords: Leadership Model, Islamic Boarding School Environment

\section{BACKGROUND}

Pesantren is one of the learning environments that has long contributed to the enlightenment of society in the Indonesia archipelago. This contribution lasted until entering the revolutionary period in Indonesia. Until now, Islamic boarding schools are still growing through charismatic kyai figures who become people's mentors throughout their lives.

The leadership of these environmental bases is often religious, with patronage from Islamic religious personalities known as kyai. As a result, a stereotype was formed in the public's mind. In a pesantren, the kyai is the lone leader. Every pesantren is typically cared for and led by a kyai, making this leader's role the one color of leadership in the pesantren environment.

In a pesantren, the presence of a kyai is like the heart of human life; he is a central, authoritative figure who is at the core of all pesantren policies and developments. Because the kyai is the founder, manager, carer, leader, and even sole owner of a pesantren, the intensity of the kyai demonstrates an authoritarian role. Many pesantren have dissolved 
as a result of their kyai's death, owing to the reasons stated above regarding the kyai's character. The kyai has no descendants who can carry on his fight. ${ }^{1}$

The pesantren's shortcoming throughout the complicated issues of contemporary Islamic education is the dynamics of the kyai's leadership, which seems authoritative and occasionally autocratic because of the kyai's only legitimacy as the pesantren's founder. From a managerial standpoint, there are also other internal issues, such as the underdeveloped pesantren. Therefore, in the pesantren setting, management must be examined in relation to the leadership model.

Leadership is one of the most fundamental aspects of all resources and the ecology of the pesantren environment. Therefore, leadership stagnation caused to the death of the kyai can hinder the pesantren's existence, and vice versa, the dynamics of pesantren leadership, might support the existence of a pesantren. As a result, it is envisaged that a dynamic pesantren leader figure will emerge to direct all pesantren resources.

According to Mastuhu, leadership in the pesantren context can be defined as the art of exploiting power in the form of funds, facilities, and pesantren personnel. The pesantren's objectives are achieved through the use of this power. As a result, efforts to move or steer diverse aspects of actors in the pesantren environment according to the intent of the pesantren leadership towards achieving goals are a type of manifestation of this power exploitation. ${ }^{2}$

The dynamics of pesantren leadership promote leader figures such as kyai to appear in ways other than their usual authoritative manner. To meet the needs of the pesantren's organizational challenges, Islamic boarding schools will inevitably need to be able to generate a more dynamic form of kyai leader. Of course, today's pesantren leaders must understand religious knowledge and the sources of Islamic ancient writings and information technology, managerial systems, and other skills necessary to deploy pesantren resources.

Furthermore, some Islamic boarding schools have established Private Islamic Religious Colleges (PTKIS) with the goal of managing universities by incorporating Islamic boarding school culture.

Private Islamic Religious College (abbreviated as PTKIS) is a private Islamic higher education unit under the Ministry of Religion which organizes religious higher education in the Islamic and non-Islamic religious sciences. The establishment of PTKIS is the establishment of private Islamic religious universities, institutes, and schools by the Organizing Body with a non-profit principle. ${ }^{3}$

The execution of PTKIS is inextricably linked to the implementation of the functions and objectives of higher education as outlined in Law No. 12 of the Republic of Indonesia on Higher Education. The mechanism of this law explains that higher education has three functions: first, developing capabilities and shaping the character and civilization of a dignified nation in the context of the nation's intellectual life; second, developing an academic community that is innovative, responsive, creative, skilled, competitive, and cooperative through the implementation of the Tri Dharma; and third, developing an academic community that is innovative, responsive, creative, skilled,

\footnotetext{
${ }^{1}$ Mukhroji, “Kepemimpinan Kyai dalam Pengasuhan Pesantren”, Jurnal Insania, Volume 16, No. 3, September-Desember 2011.

${ }^{2}$ Mastuhu, Memberdayakan Sistem Pendidikan Islam, (Ciputat: Logos Wacana Ilmu, 1999), p. 105

${ }^{3}$ Keputusan Direktur Jenderal Pendidikan Islam No. 3069 Tahun 2018 tentang “Petunjuk Teknis Izin Pendirian, Perubahan dan Pencabutan Izin Perguruan Tinggi Keagamaan Islam Swasta." p. 4
} 
competitive, and cooperative through the implementation of the Tri Dharma; and third, developing science and technology by paying attention to and applying the values of the Humanities. ${ }^{4}$

The process of implementing PTKIS must adhere to the principles of Higher Education Implementation, which include encouraging academics to seek scientific truth. By supporting human rights, religious values, cultural values, pluralism, unity, and national unity, higher education must also be conducted democratically, equitably, and without discrimination. Furthermore, the implementation of higher education is based on exemplary behavior, willingness, and the growth of learning creativity.

PTKIS is a type of private university with the same function as campuses in general in forming an innovative, responsive, creative, skilled, competitive, and cooperative character through the implementation of the Tri Dharma, as described in the three elements of the basic functions and principles of higher education as described above. At the very least, this function pushes Islamic boarding schools that run colleges to take large steps forward and look for internal culture formats that can adapt to existing standard processes. This is due to the fact that the management of pesantren differs significantly from the overall process of administering higher education, which is far more complicated.

The dynamics of pesantren in higher education management surely drive pesantren's internal leadership pattern to evolve away from its traditional image. Patrons of required kyai leaders must have acceptable scientific qualifications rather than depending solely on religious understanding. In the growth of the pesantren education system, Kyai leadership is not always authoritative and conventional. The administration of various pesantren in Indonesia exemplifies this.

According to the author's early findings, Indonesia has a number of Islamic boarding schools that are run by a dynamic, even democratic leadership style. This can be seen, for example, in the management of the DDI Mangkoso Islamic Boarding School, which has created an institutional structure to the point where PTKIS can be implemented in South Sulawesi. Internally, it is, of course, inextricably linked to the pesantren leadership concept. The DDI Mangkoso Islamic Boarding School currently has 12 (twelve) PTKIS.

This paper will try to elaborate on the leadership model of Islamic Religious Colleges within the STAI DDI Mangkoso Islamic Boarding School environment.

\section{THEORETICAL FRAMEWORK}

\section{A. Islamic Boarding School Environment Concept}

Historically, Islamic boarding schools have long grown and developed in the community in the archipelago, long before the formation of the Unitary State of the Republic of Indonesia (NKRI). Its deep-rooted history of development has made it the best educational vehicle in the Indonesian Muslim community. Marwan Saridjo argued that this pesantren institution had emerged since the end of the 14th century or the beginning of the 15th century. According to his perspective, Maulana Malik Ibrahim first established Islamic boarding schools, which was later developed further by Sunan Ampel. ${ }^{5}$

\footnotetext{
Pasal 4.

${ }^{4}$ Salinan Undang-Undang Republik Indonesia Nomor 12 Tahun 2012 tentang Pendidikan Tinggi,

${ }^{5}$ Marwan Saridjo et. al., Sejarah Pondok Pesantren di Indonesia (Jakarta: Dharma Bhakti, 1982),
} 
The Implementation of Autocratic and Charismatic Leadership Model at Islamic Higher Education in an Islamic Boarding School Environment

(Study at STAI DDI Mangkoso)

Pesantren is inextricably linked to Indonesian education discourse due to its lengthy history. The pesantren atmosphere has made a great contribution to the nation's generation's religion, heart, and character building. As a result, this contribution sees pesantren as a genuine Islamic community training center from a sociohistorical and cultural standpoint, and the process is institutionalized by the community, according to Arifin. ${ }^{6}$

Pesantren is an etymological term that simply means "learning place" or "study setting." According to M. Adib Abdurrahman, the term pesantren originally from the word "pesantrian" meant a place for santri, which refers to a permanent residence for santri. Furthermore, he added that the term "pesantren" is more broadly defined as a center of education and teaching where components of Islam's religion are heavily emphasized. Dormitory facilities, which serve as a permanent dwelling for students, aid in the learning process. $^{7}$

Majid in Bilik-Bilik Pesantren: Suatu Potret Perjalanan explained that the term pesantren comes from the word santri. This term is from Sanskrit, which means literacy. According to him, this is based on the social literacy class, which shows an effort to deepen Arabic books. From the primary word, the santri is then affixed with pe and the suffix an. This term is also in Javanese. It is often referred to as centric speech, which means people who always follow the teacher wherever the teacher goes. ${ }^{8}$

Terminologically, pesantren can be understood as an educational institution. Said Agil Syiraj, et al. explain the terminological meaning of pesantren as an environment or place where the eccentric dimension or outward appreciation of Islam is taught. ${ }^{9}$ Furthermore, Dhofier explained that Islamic boarding schools are institutions or Islamic educational institutions whose implementation is supported by a dormitory or boarding system. Kyai is a figure who instructs the students in Islam. The pesantren's institutional heart is the mosque. There are several Islamic boarding schools distributed throughout the countryside that play an important part in developing people and teaching the nation's life. ${ }^{10}$

Based on the explanation above, it can be concluded that pesantren is a cultural environment for the people of the archipelago. Pesantren is organized as the main basis of education and transformation of Islamic values. Students in it are specifically called santri who are supported by a dormitory system, generally called a boarding school. The primary teaching staff in the pesantren environment are generally kyai, making the mosque the main means and center of learning.

The pesantren environment is different from the general education environment. Maunah suggests five characteristics that can be found in a pesantren environment, including; (1) kyai who are stakeholders and teachers as well as educators; (2) Santri as students who gain knowledge from the kyai; (3) Mosque, to be a place for holding education, prayer and so on; (4) Pondok, as a residence for students. Currently, the cottage

\footnotetext{
p. 22

${ }^{6}$ Arifin, Kapita Selekta Pendidikan Islam dan Umum (Jakarta: Bumi Aksara, 1991), p. 77

${ }^{7}$ M. Adib Abdurrahman, Mencari Tipologi Pendidikan Ideal: Pondok Pesantren di Tengah Arus Perubahan (Yogyakarta: Pustaka Pelajar, 2005), h. 80

${ }^{8}$ Nurcholish Majid, Bilik-Bilik Pesantren: Suatu Potret Perjalanan (Jakarta: Paramadina, 1997), p. 99

${ }^{9}$ Said Agil Syiraj dkk, Pesantren Masa Depan, Wacana Pemberdayaan dan Transformasi Pesantren, Bandung: Pustaka Hidayah, 1999, p. 85

${ }^{10}$ Proyek Pembinaan Bantuan Kepada Pondok Pesantren Dirjen BINBAGA Islam, Pedoman Penyelenggaraan Unit Ketrampilan PondokPesantren. (Departeman Agama, 1982/1983), p. 1
} 
is generally referred to as a dormitory, which is students' residence during the education process; and (5) The existence of recitation of classical books or generally known as the study of the kitab kuning (Arabic textbook). ${ }^{11}$

Based on this explanation, it can be understood that the pesantren environment has developed far from its early appearance which tends to be traditional in nature. The changing times have encouraged many reform efforts made by kyai and santri alumni. Even today, these changes indicate that there are pesantren that house madrasas and public schools. In addition, there are Islamic boarding schools that have succeeded in developing themselves to establish universities. Thus, the kyai as a central figure also experiences personal capacity development from just being a student teacher to a managerial figure who is supported by a leadership model that is adaptive to ongoing changes.

\section{B. Leadership Model Concept}

The socio-cultural dynamics of institutions gave birth to many leadership models. Many things certainly stimulate this until the formation of various leadership models. Among the popular, leadership models are autocratic and charismatic leadership models.

1. Autocratic Model

In autocratic leadership, the leader acts as a dictator over the members of his group. An autocratic leader is a leader who has authority from a source (for example, because of his position), knowledge, strength, or power to reward or punish.

The word autocracy comes from the Greek language consisting of two syllables, namely: autos and kratos. Autos means self or personal self, Kratos is power or strength. An autocracy is a form of government in which one person holds political power. So, autocratic means absolute self-rule (centre of authority). ${ }^{12}$ All division of tasks and responsibilities is held by the authoritarian leader, while the subordinates only carry out the tasks that have been given. This leadership model's characteristics include: (a) treating the organization as a private property; (b) identifying the organization as privately owned; (c) viewing the organization as a tool; (d) refusing to accept criticism, suggestions, and opinions; and (e) employing a coercive and punitive approach frequently. ${ }^{13}$

The autocratic leadership model has its own advantages and disadvantages. The following are some of the advantages of this leadership model: a) Decisions will be made swiftly because the leader has absolute authority. b) It's simple to control. c) Goals are easier to achieve because they simply consider one person's interests. d) For the same reason, the organization has never had a conflict of interest. While the shortcomings include; a) Members of the organization cannot innovate, lack of creativity. b) Members of the organization cannot express their opinions and have no bargaining power in making decisions. c) Leaders are too powerful, so there is usually abuse of power.

\section{Charismatic Model}

Leaders of this category typically have a lot of power over their followers. His personality, which he was born with, exudes authority. As a result, this charismatic leader

\footnotetext{
${ }^{11}$ Binti Maunah, Tradisi Intelektual Santri Dalam Tantangan dan Hambatan Pendidikan Pesantren di Masa Depan, (Yogyakarta: Teras, 2009), p. 18

${ }^{12}$ Malayu Hasibuan, Manajemen Sumberdaya Menusia, (Jakarta: Bumi Aksara, 2007), p. 167

${ }^{13}$ Rivai dan Murni dalam Agustinus Hermino, Kepemimpinan Pendidikan di Era Globalisasi, (Yogyakarta: Pustaka Pelajar, 2014), p. 136
} 
frequently possesses supernatural power, and his look exudes authority, making his followers feel intrigued, amazed, and submissive. ${ }^{14}$

Charismatic leadership. Charisma is defined as a state or talent associated with extraordinary abilities in terms of one's leadership to arouse the worship and admiration of the public towards him or her leadership attributes based on individual personality qualities. ${ }^{15}$

Charismatic leaders display the following characteristics: (a) have a very strong vision or a clear sense of purpose. (b) communicate the vision effectively. (c) demonstrating consistency and focus (d) recognizing one's strengths and leveraging them. The charismatic leadership style can look similar to transformational leadership, where the leader injects great enthusiasm into the team and is very energetic in pushing it forward. However, charismatic leaders tend to believe in themselves more than their team. This can create a risk that a project or even the organization will collapse if the leader leaves.

In addition, charismatic leadership carries great responsibility and requires a longterm commitment from the leader. A charismatic leader has a distinctive characteristic; namely, his attractiveness is very alluring. He can get a huge following, and his followers cannot explain concretely why a particular person is admired. Followers do not question the values, attitudes, and behaviors, and styles used by the leader.

Charismatic leaders have a high need for power, confidence, and conviction in their own beliefs and ideals. A need for power motivates the leader to try to influence followers. Self-confidence and strong convictions increase followers' confidence in the leader's judgments and opinions. A leader who lacks such a pattern of characteristics is less inclined to try to persuade others. And if you try to influence, you are less likely to succeed.

Charismatic leadership can be interpreted as the ability to use the privilege or excess of personality traits to influence thoughts, feelings, and behavior. In an inner atmosphere of admiring and glorifying, the leader is willing to do something the leader wants. The leader here is considered special because of his amazing and authoritative personality traits. In that personality, the leader is accepted and trusted as respected, respected, obeyed, and obeyed willingly and sincerely. Charismatic leadership wants organizational members as followers to adopt the leader's views without or with little change.

\section{III.RESEARCH METHODS}

This research is an interactive qualitative research supported by descriptive quantitative analysis. This approach is carried out to be able to better describe a phenomenon, events, symptoms, and events that occur factually, systematically, and accurately. This study uses primary data obtained from the distribution of questionnaires, and also secondary data obtained from existing historical data. Data collection techniques used in this study using observation techniques, questionnaire techniques, interview techniques, and documentation techniques. The validity of the research data was checked by using triangulation.

\footnotetext{
${ }^{14}$ Ibid, p. 136

${ }^{15}$ Imron Arifin, Penelitian Kualitatif dalam Ilmu-Ilmu Social dan Keagamaan Penelitian, (Malang: Kalimasahada Press,2003), p. 34
} 


\section{IV.FINDINGS AND DISCUSSIONS}

Islamic religious university leadership is formal education leadership with a distinctive model of institutional administration and staff direction in the educational institutions they head. Individual leaders' ability to cooperate with subordinates to achieve institutional goals together is a critical part of leadership success. As a result, in the pesantren environment, coordination between interest groups must be developed, which, of course, necessitates the presence of a driving leader.

The leadership model can be thought of as a depiction of a real-world process that allows a single individual or a group of people to act on it. In terms of leadership, this model is a pattern that can be utilized as a guide for one's ideal leadership behaviors. This leadership model depicts diverse combinations of philosophy, potential, abilities, attitudes, and vision expressed in a leader's actions. The dynamics of the leadership model have a unique pattern as a process that prioritizes the completion of certain tasks to foster a cycle of collaboration for common goals. Thus, the leadership model becomes the main key in moving various potentials to achieve organizational goals.

This study analyzes the leadership model at Islamic universities in the pesantren environment of South Sulawesi with two leadership models, namely the autocratic model and the charismatic model. The findings of the data from the two leadership models at Private Islamic Religious Colleges (PTKIS) in Islamic boarding schools in South Sulawesi obtained from respondents in the form of interview data and research questionnaire, data are described as follows:

\section{A. Autocratic Leadership Indicator Analysis}

The autocratic model is one type of leadership that has the characteristics of leader-centered organizational decision-making. In this case, the decision-making process carried out is very minimal in the aspirations of subordinates so that the impression of a leader's sole control over every problem in the organization is born. The researcher developed five indicators to analyze the autocratic model at Islamic religious universities specifically related to the leadership of the Chair/Rector of STAI DDI Mangkoso and IAI As'adiyah Sengkang. The five indicators are; (1) The Chairperson/Rector considers the organization as private property; (2) The Chairperson/Rector considers the organization as a tool; (3) The Chairperson/Rector does not accept criticism, suggestions, and opinions; (4) The Chairperson/Rector often uses a coercive and punitive approach.

The results of an online interview with the Head of STAI DDI Mangkoso revealed that campus institutions are not considered private property because STAI DDI Mangkoso is legally the development of Darud Da'wah Wal Irsyad Mangkoso. This is as stated by the Head of STAI DDI Mangkoso, Prof. Dr. AGH Faried Wajedy, MA, as follows:

"STAI DDI Mangkoso cannot be assumed or positioned as a privately owned organization. This institution can be said to be an organization belonging to Muslims initiated by K.H. Abd. Rahman Ambo Dalle. Its history can be traced on the official website of STAI DDI Mangkoso, that the history of the existence of this campus began when the P-DDI deliberation was held in Pare-Pare from 11 to 14 August 1954 or coincided with 15 Zulhijjah 1373 H. Then the DDI College Preparatory Committee was formed. Chaired by K.H. Abd. Rahman Ambo Dalle and assisted by several members, such as Ust. Mahmud Yunus, Ust. Muhammad Amin Nasir, Ust.`Abd. Rahman Shihab, and Ust. M. Ali Alyafi'." (interviewed on $11 / 7 / 2021$ ) 
The Implementation of Autocratic and Charismatic Leadership Model at Islamic Higher Education in an Islamic Boarding School Environment

(Study at STAI DDI Mangkoso)

The head of STAI DDI Mangkoso also stated that the campus he leads is not only a tool, but as a muamalah worship to Islam and the state. This can be seen in the results of the interview, as follows.

'...I believe that the concept of organization as a tool is overly limited. STAI DDI Mangkoso has developed into a center for Islamic study and devotion. We educate Islamic preachers and undergraduate educators who will subsequently return to society to provide religious counsel to the general public..." (interviewed on $11 / 7 / 2021)$

Based on these interviews, it can be understood that autocratic leadership, which only views the organization as a tool, is very mechanical. STAI DDI is better understood as an instrument of transmission of knowledge and Islam. Everyone gives dedication and devotion to the organization. This encourages loyalty and creativity to achieve the goals of the organization being led.

A sensible leadership pattern is one that does not treat the organization as private property and a tool of accomplishing individual aims and interests. As a result, STAI DDI Mangkoso is a jointly owned organization that must be professionally controlled through internal methods. This can be seen in the positive impression of leadership in the STAI DDI Mangkoso environment, as stated in the excerpt from the interview with Mr. Andi Saharuddin, Vice-Chair I, as follows:

"...It is not like that. Mr Chairman has an open nature in terms of listening to suggestions and opinions. In fact, all of us as assistant vice-chancellors are always involved in making decisions at the leadership level to advance STAI DDI Mangkoso. Of course, this kind of attitude shows that his leadership is not autocratic." (Interviewed on 11/7/2021)

The excerpt from the interview shows that the leadership at STAI DDI Mangkoso has an open nature to accept various suggestions and opinions from subordinates. This is shown in the attitude of the Chairman who involves the assistants to the campus leadership in decision making. In addition, in terms of the approach to solving various problems, the leadership of STAI DDI Mangkoso does not use coercion or anything punishing. For this indicator aspect, the Chair prioritizes a persuasive approach that avoids certain penalties. This is as stated by the Vice Chair III for Student Affairs as quoted from the interview results as follows.

"I don't think I've ever encountered a coercive or punitive approach. In my observation, the head of STAI DDI Mangkoso is an elder and respected figure in this pesantren environment. Therefore, of course, his innate nature is nurturing. For example, for student affairs, he always puts forward a personal approach and of course advises students to focus more on studies. If there are lecturers or staff who are absent, they will find out what the problem is and will be given advice or warnings that are educational in nature to be more self-disciplined in working in the campus environment." (Interviewed, 11/7/2021)

The results of the interview show that autocratic leadership is not compatible with today's dynamics. Developing science encourages attitude and leadership patterns that adapt to various current situations, encouraging one's leadership model within the scope of institutions, especially Islamic religious colleges to change.

Based on the results of the interviews that have been described, it shows that the leadership at STAI DDI Mangkoso is not autocratic. This can be seen in the aspect of the 
chairman/rector not placing the institution he leads as private property. The Chancellor views the organization he leads as having a vision, mission, and goals that must be achieved together. The Chancellor has a tendency and attitude to openly accept criticism, suggestions and opinions of others in the formulation and decision making of the development of the institution he leads. In addition, in terms of solving problems, the chairperson/rector tends to use a persuasive approach and personal education, far from coercive and punitive policies. The results of these interviews can be confirmed by a description of the respondents' responses obtained through the distribution of questionnaires as described in the following table:

\section{Tabel 1. Responses to the Autocratic Leadership Model by STAI DDI Mangkoso Respondents}

\begin{tabular}{|c|l|c|c|}
\hline No & \multicolumn{1}{|c|}{ Statement } & Frequency & Percentage \\
\hline 1 & Strongly agree & 0 & 0 \\
\hline 2 & Agree & 0 & 0 \\
\hline 3 & Neutral & 27 & 36 \\
\hline 4 & Disagree & 32 & 42 \\
\hline 5 & Strongly Disagree & 16 & 22 \\
\hline \multicolumn{2}{|c|}{ Total } & 75 & 100 \\
\hline
\end{tabular}

Based on the description of the responses of STAI DDI Mangkoso respondents in the table above, it shows that there are no respondents who strongly agree or agree with the autocratic leadership pattern. STAI DDI Mangkoso respondents in the category of Disagree (36\%), Disagree (42\%), and Strongly Disagree (22\%).

The description of respondents' responses to the choice of neutral, disagree and strongly disagree statements cannot be separated from their knowledge of the autocratic leadership model, which is widely understood as an authoritarian leadership model. An autocratic leader always makes decisions without involving other people in the environment he leads. Islamic boarding schools are not compatible with this leadership model because campus management requires a lot of energy and involves many people with different scientific professional backgrounds. Therefore, in consolidating all the characteristics of academic individuals, it is not possible to apply the autocratic leadership model.

\section{B. Analysis of Charismatic Leadership Indicators}

Each leader has its authority that can make other people interested in the personality profile of the leader concerned. This kind of leadership potential is generally known as charismatic leadership. However, this leadership trait is sometimes only owned by certain individuals. In the Islamic boarding school environment, it is easy to find this kind of leadership potential in the individual kyai or in the pesantren environment in South Sulawesi known as "Gurutta".

The physical image of a charismatic leader is generally one of the determining aspects. On the other hand, the image of personality and character is far more essential to a leader who is said to be charismatic. This leadership model can be said to be born naturally in a leader who is felt by others who interact with him. The response can be in the form of admiration because of the breadth of knowledge, disposition, and personality traits that are exemplary in the pesantren environment.

Researchers try to make this leadership model one of the study variables to assess how a charismatic leader becomes a driving pawn in Islamic boarding schools in South 
The Implementation of Autocratic and Charismatic Leadership Model at Islamic Higher Education in an Islamic Boarding School Environment

(Study at STAI DDI Mangkoso)

Sulawesi, especially at the Islamic Religious College STAI DDI Mangkoso. Measuring this leadership model can be done from the respondent's point of view because the charismatic aspect of a leader cannot be measured from the leader's point of view but the impression that other people feel on the leader. Researchers conducted interviews with informants using five indicators, namely; (1) the informant believes the truth conveyed by the leader; (2) the informant accepts whatever is conveyed and done by the leader without asking; (3) informants have awareness in following the leader's orders; (4) whether the leader in an effort to achieve the organization's mission emotionally involves his followers; and (5) the leader strives for his followers to achieve high performance. The terms of the interview using the five indicators can be seen in the following description:

A leader must lead to truth, not falsehood. A leader's truth aspect provides a guarantee of conformity between thoughts and reality in the sense that something or an order given by a leader can be accepted mentally and implemented in reality. Thus, the measure of truth in a leader's orders can be understood as an assessment born of that thought and reality.

The results of interviews with informants at STAI DDI Mangkoso showed the response that the Chancellor had a charismatic spirit in the institution he led. This encourages every subordinate to accept the instructions and orders that are carried out as truth. Deputy Chairperson of STAI DDI Mangkoso, Andi Saharuddin, stated that the head of the highest campus leadership is fully responsible for running the institution. In its development, many problems that occur in the campus environment require a touch of charismatic leadership to solve various internal and external campus problems, as can be seen in the following interview excerpts:

"....In terms of the correctness of the direction of the Chairman's policy, of course, it would be wise to implement it immediately. Every direction he made was full of careful calculations so that as subordinates, both the vice-chancellor and the lecturers accepted it as the truth from a leader. In my eyes, he definitely must be judged as charismatic because the directions and policies he makes are always focused on the interests of campus development. He is firm in his implementation and controls to ensure that all directions are carried out." (Interviewed on $11 / 7 / 2021)$

A charismatic leader gives effect in every policy to subordinates who can feel that what is directed is the right policy. Therefore, in carrying out each of these directives, there is no longer any questioning. In connection with whatever was said and done by the leader without asking, Deputy Chairman I, Andi Saharuddin, stated as follows in the following excerpt from the interview:

"...yes, of course, all policies ordered by the Chairman must be implemented without question. For things that are joint planning that give birth to mutually agreed policies, of course, through long discussions because he is a very open figure. For directives that are urgent and sometimes suddenly carried out without question, in the process, it will only be known which direction they are going. For sudden directions for the benefit of the institution, his prerogative as Chairman is of course he is responsible for all of that." (Interviewed on 11/7/2021)

In line with the interview results above, Deputy Chair II, G.H. Amiruddin Usman, also stated that the policies directed were not questioned because they were always 
involved in the policy-making process. This can be seen in the following interview excerpts:

"...I think in terms of certain policies, there is no need to be questioned by a subordinate. The Chairman has greater rights in policy-making, and of course, everything is calculated and can be accounted for. On the other hand, as the vicechancellor, I also don't need to question it because it is related to ethical matters. Questioning means doubting the capacity of the Chairman, of course, in making that policy. So everything is just done. There is usually a joint evaluation to measure success and open up space for suggestions and opinions." (Interviewed on $11 / 7 / 2021$ )

The policy of the Head of STAI DDI Mangkoso is believed to have an unquestionable truth value. On the other hand, it is realized that the Chairman can account for every policy given. This is a guarantee that every subordinate will no longer question. Subordinates are happy to obey what they are told because they are emotionally involved through a shared mission connection in one STAI DDI Mangkoso institutional development group. Subordinates also are interested in contributing to the institutions they serve to achieve success based on high-performance goals. Regarding awareness in carrying out this leadership directive, Deputy Chair II, G.H. Amiruddin Usman, as quoted from the interview results, as follows:

"....it is very important to carry out the direction of the leadership (Chairman) consciously to be able to achieve success in carrying out this task. Many things are at stake. Of course, this is about the capacity of the individual who runs it, the image of the leader who gives directions and orders, the institution's good name, and so on. The directive must be executed because of the many possible failures, so it must be maximized." (Interviewed on 11/7/2021)

The researcher then explores further with regard to whether the leader (Chair) in an effort to achieve the organization's mission emotionally involves his followers. The results of the interview with Deputy Chair III of STAI DDI Mangkoso, Saparuddin Latif can be seen in the following quote:

"In terms of involvement in achieving the institutional mission is always carried out by the Chairman. All subordinates are required to carry out their respective typologies. As Vice Chair III, of course, he concentrates on student development. He (Chairman) I think has an emotional closeness with all his subordinates because he is nurturing and this institution has social capital such as kinship brotherhood in campus development." (Interviewed on 11/7/2021)

The excerpt from the interview above shows the involvement of subordinates carried out by the leadership, in this case the Head of STAI DDI Mangkoso. Involvement can help emotionally bond subordinates with leaders built within the kinship brotherhood framework in developing institutions to achieve the targeted mission. This also reflects that the Head of STAI DDI Mangkoso has the emotional intelligence to build personal networks with subordinates. This was also stated by the Deputy Chairperson of STAI DDI Mangkoso, Andi Saharuddin, as can be seen in the following interview excerpt:

"..Regarding the issue of emotional involvement in achieving the institutional mission, the Chairperson has always done it. For example, we are always motivated that all staff components in this campus are an important part in 
The Implementation of Autocratic and Charismatic Leadership Model at Islamic Higher Education in an Islamic Boarding School Environment

(Study at STAI DDI Mangkoso)

achieving the mission of the STAI DDI Mangkoso campus. The pattern of involvement is usually in terms of meetings and designing strategic agendas for campus development. During this engagement, the emotional relationship between the staff and the leadership is also closely intertwined, thus eliminating the distance. I think this is effective to encourage all components of campus developers to achieve the mission that has been formulated together." (Interviewed on 11/7/2021)

The emotional relationship between the leader and his subordinates reflects the charisma that makes others a part of one's existence. The position of office is not a barrier to encourage this emotional connection to be formed. Of course, this is an important element in the development of STAI DDI Mangkoso. This pattern of emotional connection can be realized not only through the involvement of subordinates to achieve the campus mission. But more than that, subordinates can be friends for discussion in various big ideas for campus development. This kind of involvement aligns with the campus environment as an intellectual environment that is expected to grow. The growth of this intellectual dynamic must begin with the personal contact relationship between the leader and his subordinates. This kind of relationship was also revealed in the results of an interview with Deputy Chair II of STAI DDI Mangkoso, G.H. Amiruddin Usman, as quoted from the interview as follows:

“...The Chairman of STAI DDI Mangkoso here is seen as more than just a chairman. He became a leader, a parent to many people, also became close friends and companions in many good ways. I think if it is related to charismatic matters, yes, he has that potential which makes all colleagues and other staff in this campus respect, sympathize and make him a leadership patron." (Interviewed on $11 / 7 / 2021)$

Charismatic potential does not make the leader an emotional part of others. From here, a personal relationship was established between the head of STAI DDI Mangkoso and his staff. This certainly encourages high self-confidence from the people being led by imitating the leaders in their institutions. The charismatic potential is able to encourage subordinates to establish solid relationships in working together to carry out institutional development tasks, especially within the scope of STAI DDI Mangkoso. This cannot be separated from the potential of the Chairman influencing his subordinates to achieve the mission and goals.

The last question in this interview session is how the dynamics of the leader (Chairman) strive for his followers to reach high performance and various aspects that have been addressed via the interview above. The viewpoints of the Head of STAI DDI Mangkoso and numerous Vice Chairs were gathered for this topic. The interview revealed that the Chairman, Prof. Dr. AGH Faried Wajedy, Lc., MA, places a high priority on improving the performance of all levels and employees in campus growth. This can be seen in the results of the interview, as follows:

"...The matter of high performance is a must, not only subordinates but also leaders are highly required to have good performance. For the staff and lecturers here they are expected to have a good performance. As the Head of STAI DDI Mangkoso, I guarantee and provide room for actualization so that everyone has the same opportunity. So that motivation, direction, guarantee of career development, and guidance through many institutional trainings are carried out to 
increase the capacity of human resources. If the campus HR is good, it can automatically show high performance." (Interviewed on 11/7/2021)

The researcher then confirmed the interview with the Deputy Chairperson of STAI DDI Mangkoso. Deputy Chair I, Mr Andi Saharuddin, said that the Chair prioritized the performance of the leadership, staff, and lecturers in the STAI DDI Mangkoso campus. This can be seen in the interview excerpt as follows.

"Performance is critical in moving the institution forward, particularly in terms of providing da'wah and education services to the community. This is something we all understand, so the Chairman has committed to urge everyone who works here to do their best and keep improving. Work motivation, training, and even career guarantees are generally given to those who perform well and are promoted to certain positions to encourage this behaviour. Here, great performance must be an institutional culture in which everyone has an equal chance to succeed." (Interviewed on 11/7/2021)

In line with the results of the interview, Deputy Chair II, G.H. Amiruddin Usman, also stated the following:

"I think performance is the main focus of Mr Chairman. The Vice-Chairs were also asked to be passionate about performance as an example for others. Staff are encouraged to improve performance through service. Lecturers are also encouraged to improve their knowledge. Staff who perform well are usually proposed for certain positions. Meanwhile, lecturers are usually supported through research, training, and scholarship opportunities for doctoral degrees." (Interviewed on 11/7/2021)

The excerpt from the interview shows that the performance of the leadership, staff, and lecturers at the STAI DDI Mangkoso campus is an important thing that is the Chair's focus as a leader. This was also confirmed by Deputy Chair III (Mr. Saparuddin Latif), as quoted from the interview results as follows:

"....In terms of efforts to achieve good performance, the Chairman always emphasizes the aspect of self-development. As Deputy Chairperson, he is also directed to motivate fellow staff and lecturers. Many training agendas are carried out on a campus-scale to empower internal resources. Young lecturers are also encouraged to do research and write books, and so on. All of this is a joint effort initiated by the campus leadership, in this case, the Head of STAI DDI Mangkoso." (Interviewed on 11/7/2021)

Based on the excerpts from the interviews above, it can be concluded that high performance is one of the important aspects in the STAI DDI Mangkoso campus environment. As the institution leader, the Head of STAI DDI Mangkoso seems to really encourage the achievement of high performance. Therefore, various ways are done, for example, providing motivation, providing space for career development, training, research for lecturers, etc. This is done to achieve good performance in the STAI DDI Mangkoso environment.

Based on the interviews above, it can be stated that the performance aspect shows the quality of individuals and campus institutions. The high-performance aspect reflects the level of achievement as a campus success which is reflected in the work ethic. The leadership must also encourage this performance to produce service process outcomes in 
the campus environment they lead. Charismatic leaders believe to encourage their followers to achieve this performance through various series of productive activities directed at achieving the goals of the campus they lead.

Charismatic leaders often maintain their behaviour in front of their subordinates so that they seem competent in their fields. A charismatic leader is good at voicing his ideology related to organizational goals to create shared aspirations that are accommodated to his subordinates.

Charismatic leaders engage in behaviours that are perceived as new, unconventional, and against the norm. When successful, this behaviour generates the surprise and admiration of followers. Charismatic leadership relates to respect, collective identity, and to group performance, and is indirectly related to trust, satisfaction, and empowerment. Exemplary is the basis for followers' interest in leadership is the perception of the leader who is seen as highly valued as someone who can set an example for his followers.

Based on the results of the discussion above, it can be concluded that the leadership at STAI DDI Mangkoso reflects a charismatic leadership model. This can be seen in subordinates; (1) believe in the truth of the leader; (2) accept and do what is conveyed by the leadership without having to ask; (3) in carrying out tasks based on awareness to follow the direction of the leadership; (4) the leadership in this case the Chancellor seeks to encourage his subordinates in achieving the mission of the campus institution he leads; and (5) the Chancellor as a leader encourages through various efforts to empower his subordinates to have high performance. This conclusion can be legitimized by the description of respondents' responses on the two campuses obtained through the distribution of questionnaires as the results are described in table 3 and table 4 below:

\section{Tabel 3. Responses to the Charismatic Leadership Model by STAI DDI Mangkoso} Respondents

\begin{tabular}{|c|l|c|c|}
\hline No & \multicolumn{1}{|c|}{ Statement } & Frequency & Percentage \\
\hline 1 & Strongly agree & 29 & 38 \\
\hline 2 & Agree & 43 & 58 \\
\hline 3 & Neutral & 3 & 4 \\
\hline 4 & Disagree & 0 & 0 \\
\hline 5 & Strongly Disagree Total & 0 & 0 \\
\hline & \multicolumn{2}{r|}{75} & 100 \\
\hline
\end{tabular}

The description in table 2 above shows a description of respondents' responses at the STAI DDI Mangkoso campus. All respondents have positive responses to the charismatic leadership model. This can be seen in the achievement of the average statement of respondents in the choice of statements Strongly Agree and Agree. At the STAI DDI Mangkoso campus, respondents in the statement Strongly Agree (38\%) and Agree (58\%). The results of this statement also show that leadership in a pesantren-based university environment has a charismatic model. The kyai or taught figures have specific behaviours that reflect their charisma in nurturing and leading the pesantren environment.

In addition, ideally the charismatic leadership model can be accepted by all environments. Charismatic leaders inspire and motivate followers to commit to goals. They fit in an environment where people need the presence of individuals who are able to move and change the status quo. The charismatic leadership style works well during urgent organizational changes. They are also important when organizations are 
undergoing fundamental change. They are very good at motivating followers to do whatever it takes. In such situations, the leader is considered to have extraordinary abilities. Subordinates and other stakeholders believe and trust the leader to bring about change for the better. It brings out positive energy among followers. They voluntarily follow orders with high trust.

Based on the discussion that has been described above, it can be concluded that the leadership model of Islamic Religious Colleges in the South Sulawesi Islamic Boarding School environment, especially on the STAI DDI Mangkoso campus applies the values of the charismatic leadership model. Meanwhile, the autocratic model was not applied because it was considered too rigid in terms of managing the pesantren.

\section{CLOSING}

Based on the explanation above, the results of this study show that the leadership model of Islamic Religious Colleges in Islamic boarding schools includes; (1) the autocratic leadership model is not applied in the STAI DDI Mangkoso environment. This is reinforced by the responses of respondents at the level of statements Disagree (36\%), Disagree (42\%), and Strongly Disagree (22\%). (2) the charismatic leadership model is applied at STAI DDI Mangkoso with respondents' responses to the choices of statements Strongly Agree (38\%) and Agree statements (58\%).

\section{REFERENCES}

Mukhroji, “Kepemimpinan Kyai dalam Pengasuhan Pesantren”, Jurnal Insania, Volume 16, No. 3, September-Desember 2011.

Mastuhu, Memberdayakan Sistem Pendidikan Islam. Ciputat: Logos Wacana Ilmu, 1999.

Keputusan Direktur Jenderal Pendidikan Islam No. 3069 Tahun 2018 tentang "Petunjuk Teknis Izin Pendirian, Perubahan dan Pencabutan Izin Perguruan Tinggi Keagamaan Islam Swasta."

Salinan Undang-Undang Republik Indonesia Nomor 12 Tahun 2012 tentang Pendidikan Tinggi, Pasal 4.

Marwan Saridjo et. al., Sejarah Pondok Pesantren di Indonesia. Jakarta: Dharma Bhakti, 1982.

Arifin, Kapita Selekta Pendidikan Islam dan Umum. Jakarta: Bumi Aksara, 1991.

M. Adib Abdurrahman, Mencari Tipologi Pendidikan Ideal: Pondok Pesantren di Tengah Arus Perubahan. Yogyakarta: Pustaka Pelajar, 2005.

Nurcholish Majid, Bilik-Bilik Pesantren: Suatu Potret Perjalanan. Jakarta: Paramadina, 1997.

Said Agil Syiraj dkk, Pesantren Masa Depan, Wacana Pemberdayaan dan Transformasi 
The Implementation of Autocratic and Charismatic Leadership Model at Islamic Higher Education in an Islamic Boarding School Environment

(Study at STAI DDI Mangkoso)

Pesantren, Bandung: Pustaka Hidayah, 1999.

Proyek Pembinaan Bantuan Kepada Pondok Pesantren Dirjen BINBAGA Islam, Pedoman Penyelenggaraan Unit Ketrampilan PondokPesantren. Departeman Agama, 1982/1983.

Binti Maunah, Tradisi Intelektual Santri Dalam Tantangan dan Hambatan Pendidikan Pesantren di Masa Depan. Yogyakarta: Teras, 2009.

Malayu Hasibuan, Manajemen Sumberdaya Menusia. Jakarta: Bumi Aksara, 2007.

Rivai dan Murni dalam Agustinus Hermino, Kepemimpinan Pendidikan di Era Globalisasi. Yogyakarta: Pustaka Pelajar, 2014.

Imron Arifin, Penelitian Kualitatif dalam Ilmu-Ilmu Social dan Keagamaan Penelitian. Malang: Kalimasahada Press, 2003. 